\title{
Physiological and Morphological Characteristics of Stationary Phase Vibrio Cells Able to Support Phage Growth
}

\author{
By SUSAN M. ROBB, F. T. ROBB AND D. R. WOODS* \\ Department of Microbiology, University of Cape Town, \\ Private Bag, Rondebosch 7700, Cape Town, South Africa
}

(Received 14 November 1979; revised 5 March 1980)

Growth of phage $\alpha 3 \mathrm{a}$ on stationary phase Vibrio cultures requires micro-aerophilic conditions and is inhibited by aeration. Since pre-conditioning of the bacteria by allowing them to stand for $24 \mathrm{~h}$ after shaking for $3 \mathrm{~d}$ is an important aspect of the stationary phase phage growth system, various physiological and morphological characteristics of the stationary phase cells during the transition from shaking to standing were investigated. Shaken stationary phase cells were less viable and more sensitive to ultraviolet irradiation and heat than standing stationary phase cells. During pre-conditioning the small, non-flagellated cells present in shaken stationary phase cultures underwent morphological changes and became large, flagellated rods which resembled exponential phase cells. The transition of stationary phase cells from shaking to standing was associated with a marked increase in total RNA synthesis but a rapid and large decrease in total protein synthesis. Intracellular concentrations of ATP in shaken stationary phase cells were $53 \%$ lower than those in standing stationary phase cells. Studies on leucine uptake indicated that its transport was inhibited by isoleucine and that the major part $(90 \%)$ of the total leucine uptake was due to a shared system for uptake of both amino acids. Shaken stationary phase cells transported less leucine than standing stationary phase cells. Inhibition of phage growth in aerated stationary phase cultures was not due to the prevention of phage adsorption by shaking. It is suggested that the observed differences between shaken and standing stationary phase cells could be due to aeration affecting the template specificity of the Vibrio RNA polymerase.

\section{INTRODUCTION}

Bacteriophage growth specifically requiring stationary phase bacteria is a unique phenomenon, first reported by Woods (1976) who described a system in which phage $\alpha 3$ a grows on stationary phase Achromobacter strain 14 mutant cells but is unable to develop in exponential phase cells of the same strain. The parent strain was isolated from hides and is an aerobic, halotolerant, collagenolytic Gram-negative bacterium which was originally classified as an Achromobacter strain (Thomson et al., 1972). This identification was confirmed by the National Collection of Industrial Bacteria, Aberdeen, Scotland, but has since been reinvestigated and the organism is now classified as a Vibrio strain.

In addition to the original strain 14 mutant described by Woods (1976), we isolated a rifampicin-resistant mutant which supported phage $\alpha 3 \mathrm{a}$ growth in both exponential and stationary phase cells (Robb et al., 1977). The rifampicin-resistant mutant had an altered RNA polymerase and it was suggested that the phenomenon of stationary phase phage growth could be due to a change in the template specificity of the bacterial RNA polymerase. 
The micro-environment is very critical for stationary phase phage growth and the system requires micro-aerophilic conditions (Woods, 1976; Robb et al., 1977). Stationary phase phage growth occurs in standing cultures but not in either shaken (aerated) or stringent anaerobic cultures (Woods, 1976). Robb et al. (1978) investigated the kinetics of phage $\alpha 3 a$ growth on stationary phase cells and reported that the system is characterized by a long and variable latent period of 6 to $9 \mathrm{~h}$ and an increased burst size of 710 plaque-forming units (p.f.u.) cell ${ }^{-1}$ as compared with about 150 p.f.u. cell ${ }^{-1}$ in exponential phase wild-type cells. An important aspect of the stationary phase phage growth system involved pre-conditioning the cells by allowing them to stand for $24 \mathrm{~h}$ after shaking for $3 \mathrm{~d}$. Shaken stationary phase cells do not support phage growth and the 6 to $9 \mathrm{~h}$ latent period is increased to $18 \mathrm{~h}$ when $3 \mathrm{~d}$ shaken cultures are not pre-incubated without aeration for $24 \mathrm{~h}$ (not pre-conditioned) before the addition of phage. Stationary phase cells which have been allowed to stand retain the ability to be infected and to support phage growth for at least $16 \mathrm{~d}$. Shaken cultures gradually lose the ability to support phage growth (after standing for $24 \mathrm{~h}$ ) but the phage can persist in the host cell for $10 \mathrm{~d}$ until removal from shaking when the lytic cycle can proceed after allowing the cultures to stand.

Since pre-conditioning of the stationary phase cells is so important for the novel phage growth system, we have studied various physiological and morphological characteristics of the stationary phase cells during the transition from shaking to standing. As phage growth requires the synthesis of proteins and nucleic acids, the effect of aeration on the synthesis of macromolecules and intracellular ATP concentrations was investigated. The bacterium and related Vibrio strains produce extracellular collagenase and proteases in aerated stationary phase cultures (Thomson et al., 1972; Lecroisey et al., 1975). Since enzymes are available in shaken cultures for the degradation and recycling of amino acids from extracellular proteins, the effect of aeration on an amino acid transport system was investigated. Furthermore, the possibility that differences in protein synthesis could be due to variations in the uptake of amino acids was examined. The general viability of standing and shaken stationary phase cultures and their ability to adsorb phage were also determined.

\section{METHODS}

Media. The tryptone medium of Thomson \& Woods (1973) was used for bacterial growth and for doubleagar-layer phage assays. Incubation was at $30^{\circ} \mathrm{C}$.

Bacteria and bacteriophages. The mutant strain previously isolated and classified as an Achromobacter strain 14 but recently reclassified as a Vibrio strain 14 was used (Woods \& Thomson, 1975; Woods, 1976). This strain was used for stationary phase phage growth and for the physiological and morphological studies. The wild-type Achromobacter sp. 2 (Thomson et al., 1972) which has keen reclassified as the wild-type Vibrio sp. 2 was used as the indicator strain for plaque assays. The double-stranded DNA phage $\alpha 3 \mathrm{a}$ isolated by Thomson \& Woods (1974) was grown on the Vibrio strains.

Stationary phase cells. Stationary phase Vibrio strain 14 cultures were routinely prepared by growing the cells in $600 \mathrm{ml}$ tryptone broth in a 11 conical flask on a Gallenkamp rotary shaker at $250 \mathrm{rev} \cdot \mathrm{min}^{-1}$ for $3 \mathrm{~d}$ (about $2 \times 10^{9}$ cells ml $^{-1}$ ) (Robb et al., 1978). The culture was then divided: aeration of one half was continued (shaken culture) while the other half was dispensed in $3 \mathrm{ml}$ volumes in test tukes $(12 \times 75 \mathrm{~mm})$ or $10 \mathrm{ml}$ volumes in $28 \mathrm{ml}$ screw-capped containers and incubated aerobically without shaking (standing cultures). The conditions obtained after $24 \mathrm{~h}$ standing have teen shown to te optimal for stationary phase phage growth (Robb et al., 1978). The viability of shaken and standing stationary phase cells was determined by plating at different times after the initial $3 \mathrm{~d}$ aeration.

Ultraviolet and heat inactivation. Standing and shaken stationary phase Vibrio strain 14 cells were diluted 100 -fold in cold phosphate buffer pH 7.2 $\left(2 \times 10^{7} \mathrm{cells} \mathrm{ml}^{-1}\right)$ and heated at $60^{\circ} \mathrm{C}$ or irradiated with a Hanovia filtered germicidal lamp which emits $>85 \%$ of its output at $254 \mathrm{~nm}$ at an intensity of $0.55 \mathrm{~J} \mathrm{~m}^{-2} \mathrm{~s}^{-1}$ at a distance of $22 \mathrm{~cm}$. Cell samples $(7 \mathrm{ml})$ were irradiated in open Petri dishes which were continuously agitated. Irradiation was carried out in the dark and post-irradiation manipulations in subdued light and the plates were incubated in the dark. After heating or irradiation for different periods, the cells were diluted and plated.

Phage adsorption. Phage $\alpha 3$ a was added to shaken and standing stationary phase cultures $\left(2 \times 10^{9}\right.$ cells $\mathrm{ml}^{-1}$ ) at a multiplicity of infection of $10^{-3}$ and incubated at $30^{\circ} \mathrm{C}$. Samples were removed at different times, 
diluted 1000-fold, treated with toluene for $15 \mathrm{~min}$ at room temperature and assayed for free phage (Robb et al., 1978).

Nucleic acid synthesis. The amount of DNA and RNA synthesis in shaken and standing stationary phase cells, as well as aerated exponential phase cells, was determined as descrited previously (Woods, 1976). RNA synthesis was determined by incorporation of $\left[{ }^{3} \mathrm{H}\right]$ uracil $\left[2 \mu \mathrm{g} \mathrm{ml}^{-1}, 0 \cdot 4 \mu \mathrm{Ci} \mathrm{m}^{-1}\left(15 \mathrm{kBq} \mathrm{ml}^{-1}\right)\right]$ into trichloroacetic acid (TCA)-precipitable material. As the Vibrio strains did not incorporate $\left[{ }^{3} \mathrm{H}\right]$ thymidine, DNA synthesis was determined by incorporation of $\left[{ }^{3} \mathrm{H}\right]$ adenine $\left[2 \mu \mathrm{g} \mathrm{ml}^{-1}, 0.4 \mu \mathrm{Ci} \mathrm{ml}^{-1}\left(15 \mathrm{kBq} \mathrm{ml}^{-1}\right)\right]$ into $\mathrm{NaOH}$-hydrolysed TCA-precipitable material. The sampling procedure for assaying nucleic acid synthesis in standing stationary phase cells was the same as that descrited for protein synthesis determinations (see kelow).

Protein synthesis. Protein synthesis was measured by the incorporation of $\left[{ }^{14} \mathrm{C}\right]$ leucine into TCA-precipitable material (Eichenlaub \& Winkler, 1974). Unlatelled leucine $\left(10 \mu \mathrm{g} \mathrm{ml}^{-1}\right)$ and $\left.{ }^{1{ }^{4}} \mathrm{C}\right]$ leucine $\left(1 \mu \mathrm{Ci} \mathrm{ml}{ }^{-1}\right.$, $37 \mathrm{kBq} \mathrm{ml}^{-1}$ ) were added to $3 \mathrm{ml}$ shaken and standing stationary phase cultures. For assaying leucine incorporation in the standing cultures, leucine was added to a number of identical $3 \mathrm{ml}$ cultures at time 0 . At each sampling time, samples were taken from a different culture which was then discarded. This was to ensure that the aeration conditions of the standing cultures were not altered during sampling as Robb et al. (1978) showed that standing cultures which were repeatedly opened and moved during sampling did not support phage growth.

Intracellular ATP concentrations. Intracellular ATP was measured by the luciferin-luciferase assay by counting the flashes of light emitted by mixtures of cell extracts and firefly lantern extracts (Sigma) by the method of Foulds (1971).

Leucine transport. Exponential and stationary (shaken and standing) phase cells were washed twice by centrifugation and resuspension in phosphate buffer $\mathrm{pH} 6.9$ at room temperature. The cell density was adjusted turbidimetrically to $1 \times 10^{9}$ cells $\mathrm{ml}^{-1}$. The leucine-specific and LIV (leucine, isoleucine and valine) systems (Wood, 1975) were assayed essentially as descriked by Rahmanian et al. (1973). Cells (50 $\mu$ l) were added to $50 \mu \mathrm{l}$ of double-strength transport buffer and held for $60 \mathrm{~s}$ tefore starting the reaction by adding $50 \mu \mathrm{l}\left[{ }^{14} \mathrm{C}\right]$ leucine (final concentration $\left.10 \mu \mathrm{M}\right)$. All the assay mixtures contained chloramphenicol $(50 \mu \mathrm{g}$ $\left.\mathrm{ml}^{-1}\right)$, glucose $(0.5 \%, \mathrm{w} / \mathrm{v})$ as the energy source and $0.4 \mathrm{M}-\mathrm{NaCl}$. Transport was measured at $20^{\circ} \mathrm{C}$ and the reactions were stopped after $15,30,45,60$ and $120 \mathrm{~s}$ by filtration of $100 \mu 1$ samples and washing with buffer on $0.45 \mu \mathrm{m}$ (pore size) membrane filters (Gelman Instrument Co.). Each nmol leucine was represented by 209000 c.p.m. The leucine and LIV systems were assayed together in the absence of isoleucine and the leucine-specific system was measured by leucine uptake in the presence of $200 \mu \mathrm{M}$-isoleucine which completely inhibits the LIV system in Escherichia coli (Rahmanian et al., 1973). The LIV system was determined by difference. Protein was determined by the Folin method of Lowry.

Cell morphology. The morphologies of exponential and stationary (shaken and standing) phase cells were investigated. Wet mounted specimens were observed with a Zeiss photomicroscope fitted with phase contrast optics. Glutaraldehyde-fixed and metal-shadowed specimens were examined with a Jeol JSN U3 scanning electron microscope. Metal-shadowed bacterial suspensions were observed with a Hitachi HU $11 B$ transmission electron microscope.

\section{RESULTS}

Viability of stationary phase cells. The viability of stationary phase cells was affected by aeration (Fig. 1). Shaken stationary phase cells showed an immediate and almost exponential decrease in viable count from $2.7 \times 10^{9}$ to $1.5 \times 10^{7}$ cells $\mathrm{ml}^{-1}$ after $18 \mathrm{~d}(0.55 \%$ survival $)$. The survival of standing stationary cultures was characterized by a shoulder from 3 to $7 \mathrm{~d}$ and after $18 \mathrm{~d}$ the viable count was $2 \times 10^{8}$ cells $\mathrm{ml}^{-1}(8.33 \%$ survival). The total microscopic cell count remained constant in both the shaken and standing cultures and lysis was not observed.

Ultraviolet and heat inactivation. Standing stationary phase cells were more resistant to u.v. irradiation than shaken stationary phase cells (Fig. 2). The u.v. survival curve of standing cells was characterized by a pronounced shoulder and $66 \%$ of the bacteria survived after $60 \mathrm{~s}$ irradiation compared with a survival of $0.1 \%$ in the shaken culture. Standing stationary phase cells were also more resistant to inactivation by heat. After $30 \mathrm{~min}$ at $60{ }^{\circ} \mathrm{C}$ the viable counts had decreased from $1.7 \times 10^{7}$ to $6.3 \times 10^{3}$ and $<1 \times 10^{2}$ cells $\mathrm{ml}^{-1}$ for standing and shaken cultures, respectively.

Phage adsorption. Phage $\alpha 3 \mathrm{a}$ adsorption to shaken stationary phase cells was greater than to standing stationary phase cells. The percentage of phage adsorbed after $30 \mathrm{~min}$ with 


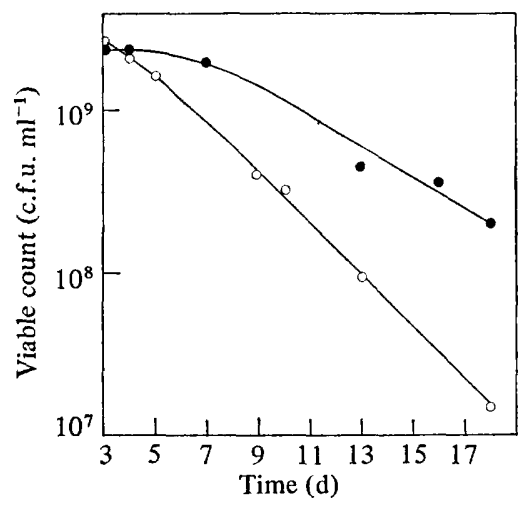

Fig. 1

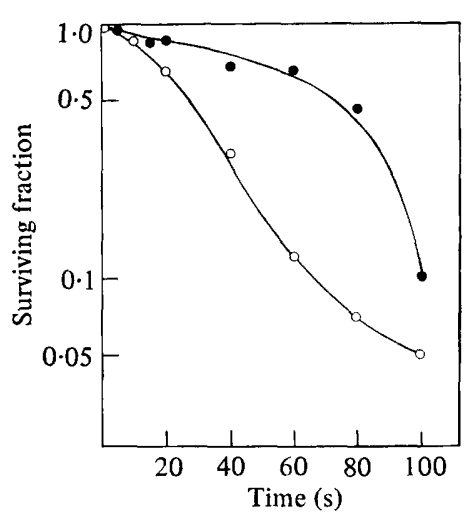

Fig. 2

Fig. 1. Viability of stationary phase aerated and non-aerated Vibrio strain 14 cultures. A culture was grown with shaking for $3 \mathrm{~d}$ before being divided: aeration of one half was continued $(O)$ while the other half was dispensed and allowed to stand (O).

Fig. 2. Survival of u.v.-irradiated Vibrio strain 14 stationary phase cells. Shaken $(O)$ and standing (O) stationary phase cells were diluted 100 -fold in phosphate buffer $\left(2 \times 10^{7}\right.$ cells $\left.^{-1}\right)$ and u.v.irradiated at $254 \mathrm{~nm}$ at an intensity of $0.55 \mathrm{~J} \mathrm{~m}^{-2} \mathrm{~s}^{-1}$.

shaken cells was $54 \%$ (average of five experiments) compared with $44 \%$ (average of five experiments) with standing cells.

Nucleic acid synthesis. Woods (1976) investigated nucleic acid synthesis in stationary phase cells and reported that DNA synthesis was not observed in shaken or standing stationary phase cultures. No RNA synthesis was detected in shaken stationary phase cultures but RNA synthesis occurred in standing stationary phase cultures. The incorporation of $\left[{ }^{3} \mathrm{H}\right]$ uracil into standing stationary phase cells over 60 min was $50 \%$ of that into exponential phase cells. As Robb et al. (1978) had shown that the sampling technique for detecting stationary phase phage growth markedly affected phage growth, it was considered important to re-examine nucleic acid synthesis using their technique. Although different sampling techniques were utilized the results obtained by Woods (1976) were essentially confirmed except that very low levels of DNA synthesis $(0.88 \%$ of that in exponential cultures after $60 \mathrm{~min}$ ) were detected in shaken stationary phase cultures.

Protein synthesis. Studies on the incorporation of $\left[{ }^{1} \mathrm{C}\right] l$ leucine into protein indicated that protein synthesis was markedly reduced in standing stationary phase cultures compared with that in shaken stationary phase cultures (Fig. 3). In seven different experiments protein synthesis in standing stationary phase cultures never exceeded $4 \%$ of that in shaken stationary phase cultures. Protein synthesis in shaken stationary phase cultures was $38.5 \%$ of that in exponential phase cultures after $30 \mathrm{~min}$ incorporation of $\left[{ }^{14} \mathrm{C}\right]$ leucine. In standing stationary phase cultures protein synthesis was $0.5 \%$ of that in exponential phase cultures. An experiment was carried out to determine whether the low $\left[{ }^{14} \mathrm{C}\right]$ leucine incorporation into proteins in standing stationary phase cells was attained gradually during the $24 \mathrm{~h}$ standing period. A $3 \mathrm{~d}$ old shaken culture was dispensed into standard containers $(10 \mathrm{ml})$ and into $12 \times 75 \mathrm{~mm}$ test tubes $(3 \mathrm{ml})$ and placed at $30^{\circ} \mathrm{C}$. Incorporation of $\left[{ }^{14} \mathrm{C}\right]$ leucine was measured over $30 \mathrm{~min}$ in samples which had been standing for 0 to $24 \mathrm{~h}$. Incorporation of $\left[{ }^{14} \mathrm{C}\right]$ leucine immediately after dispensing and standing was $2 \%$ of that in the parent shaken culture. From 0 to $24 \mathrm{~h}$ there was no variation in the level of protein synthesis in the standing cultures. There was therefore an immediate and almost total reduction in protein synthesis in changing from shaking to standing conditions.

Intracellular ATP concentrations. Intracellular ATP concentrations of shaken exponential phase, standing stationary phase and shaken stationary phase cells were, respectively, $54 \cdot 4$, 


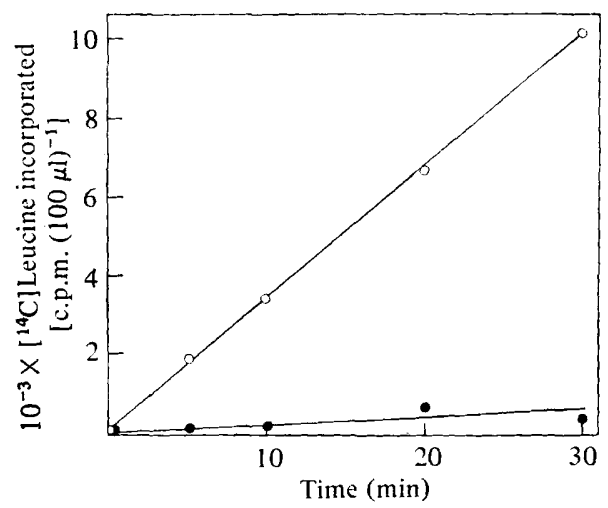

Fig. 3. Protein synthesis in shaken and standing stationary phase Vibrio strain 14 cultures. Incorporation of $\left[{ }^{14} \mathrm{C}\right]$ leucine in shaken $(O)$ and standing $(O)$ cultures.

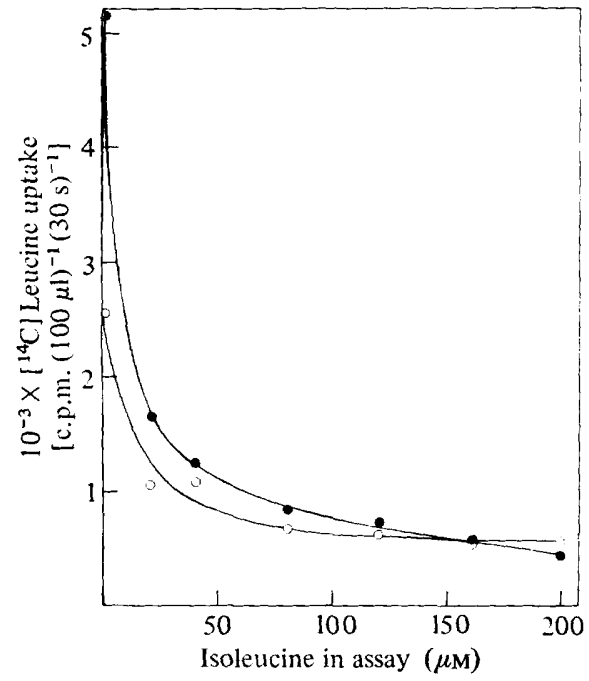

Fig. 4

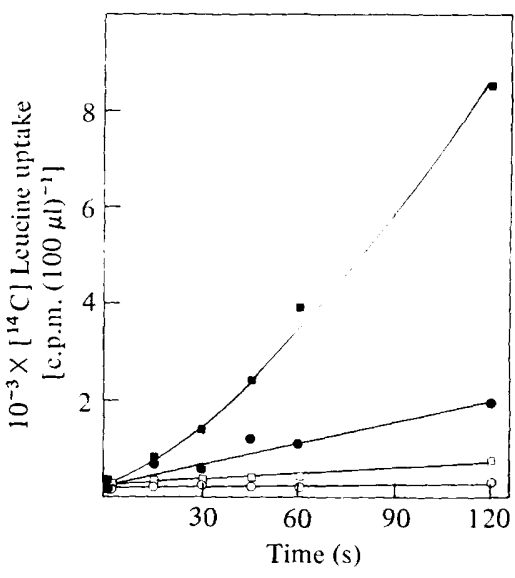

Fig. 5

Fig. 4. Leucine uptake by exponential phase wild-type Vibrio sp. 2 cells in the presence of different concentrations of isoleucine. Uptake of $\left[{ }^{14} \mathrm{C}\right]$ leucine by cells grown in the absence $(O)$ or presence (O) of leucine $\left(5 \mathrm{mg} \mathrm{ml}^{-1}\right)$.

Fig. 5. Leucine uptake by stationary phase Vibrio strain 14 cells. Uptake of $\left[{ }^{1} \mathrm{C}\right]$ leucine in shaken $(\boldsymbol{O})$ and standing ( $\square$ ) stationary phase cells without isoleucine and in shaken $(O)$ and standing ( $\square$ ) stationary phase cells in the presence of $200 \mu \mathrm{M}$-isoleucine.

43.9 and $23.3 \mathrm{pmol}$ (mg protein $)^{-1}$. Thus, ATP concentrations in standing stationary phase cells were $80 \%$ of those in exponential phase cells, and concentrations were $53 \%$ lower in shaken stationary phase cells than in standing stationary phase cells.

Leucine transport. As the kinetics of leucine uptake in Vibrio cells had not been investigated previously it was initially studied in exponential phase Vibrio wild-type cells which had been grown in minimal medium (Woods \& Thomson, 1975). The uptake of leucine over $30 \mathrm{~s}$ was measured with increasing concentrations of isoleucine in the assay mixture (Fig. 4). Isoleucine inhibited $90 \%$ of the leucine uptake (major transport system) but did not affect the remaining $10 \%$ of leucine transport activity.

The growth of Vibrio cells in a medium containing $5 \mathrm{mg}$ leucine $\mathrm{ml}^{-1}$ enhanced the major 
transport system (Fig. 4) which has a $K_{\mathrm{m}}$ of approximately $2 \mu \mathrm{M}$-leucine (unpublished results). Uptake rates for cells grown in tryptone and minimal medium were 0.06815 and $0.05532 \mathrm{nmol}$ leucine ( $A$ unit) $)^{-1} \mathrm{~min}^{-1}$, respectively. The levels of active transport of leucine into stationary phase Vibrio strain 14 cells were low in shaken cultures compared with standing cultures (Fig. 5). After $120 \mathrm{~s}$ cells from the standing culture had transported about four times more $\left[{ }^{14} \mathrm{C}\right]$ leucine across the membrane than cells from the shaken culture. As in exponential phase cells the major leucine transport system was inhibited by isoleucine and reduced to about $10 \%$ of that measured without isoleucine in cells from both standing and shaken cultures.

Cell morphology. Exponential phase cells were large, flagellated (peritrichous), motile rods. Many dividing cells were observed in exponential phase cultures. In contrast, shaken stationary phase cells were small (about $1.3 \times 0.7 \mu \mathrm{m}$ ), non-flagellated and non-motile. After standing for $24 \mathrm{~h}$ the cells increased in size (about $3 \times 1.25 \mu \mathrm{m}$ ), resynthesized an abundance of peritrichous flagella and resembled exponential phase cells. Although cells from standing cultures were motile they tended to form filaments of cells linked end to end. By $12 \mathrm{~h}$ after the addition of phage $\alpha 3$ a the cells from standing cultures had increased slightly in width, become highly motile and the filaments had disappeared.

\section{DISCUSSION}

Studies on the transition from shaking to standing in stationary phase Vibrio cells were undertaken with a view to understanding how vigorous aeration inhibited $\alpha 3 a$ phage development during the stationary growth phase. Adsorption of phage was better in aerated than in standing stationary phase cultures. Therefore, the inhibition of phage development in shaken cultures is not due to inhibition of phage adsorption.

Interesting changes in RNA and protein synthesis occur when shaken stationary phase cells are allowed to stand. RNA synthesis is not detected in shaken stationary phase cells. These cells are not able to support phage growth in contrast to standing stationary phase cells. A possible explanation is that phage growth is prevented in shaken stationary phase cells because transcription is completely or partially inhibited by aeration. Complete inhibition of RNA synthesis is unlikely as the high rates of protein synthesis over long periods of aeration indicate that mRNA synthesis is occurring. The synthesis of unstable mRNA can be difficult to detect in stationary phase cells (Nierlich, 1978). Alterations in template specificity of the Vibrio RNA polymerase may be affected by aeration and as a result the phage genome is not transcribed. In a similar way, variations in template specificity of the Vibrio RNA polymerase were suggested by Robb et al. (1977) to account for the isolation of a rifampicin-resistant mutant with an altered RNA polymerase which supported $\alpha 3 \mathrm{a}$ phage growth in stationary phase cells. The ability of the RNA polymerase from shaken and standing stationary phase cells to synthesize RNA from a purified $\alpha 3$ a DNA template in vitro is being investigated to determine whether aeration affects template specificity. Stationary phase cells are capable of adapting to the environment by changes at the transcriptional level (Mandelstam, 1957) and bacterial endospore formation is a morphological example of this type of differentiation (Pine, 1972).

It is not known whether the stimulation of RNA synthesis in standing stationary phase cells represents proportionate increases in mRNA, rRNA and tRNA, whether one class is favoured or what role degradation of RNA plays in this apparent stimulation. It is likely that the increase observed in RNA synthesis is due to changes in the regulation of stable RNA since mRNA usually constitutes a minor fraction of total bacterial RNA and is independent of growth rate in E. coli (Forchhammer \& Lindahl, 1971; Norris \& Koch, 1972). The increase in total RNA synthesis on standing indicates the presence of a reserve transcriptional capacity but the control of this synthesis is not known and could involve the concentration of RNA polymerase, ATP, GTP and ppGpp (Nierlich, 1978). Studies are 
being undertaken to determine the levels of RNA polymerase and ppGpp in shaken and standing stationary phase cells.

The finding that protein synthesis showed an opposite response to that of RNA synthesis when stationary phase cells were removed from aeration was unexpected. During growth, bacteria respond to changes in the environment by increasing or decreasing RNA and protein proportionately over the same period of time (Mandelstam, 1960). The stringent response caused by the starvation of an amino acid results in the inhibition of protein synthesis and a reduction in RNA synthesis. It was suggested previously that aeration could affect the control of transcription in stationary phase Vibrio cells. The inability to control the template specificity of RNA polymerase in aerated stationary phase cells could also account for the high levels of protein synthesis in the small unhealthy cells from shaken stationary phase cultures. Non-specific and erroneous transcription in aerated stationary phase cells could result in a 'sick' uncontrolled protein synthesis similar to that in relaxed mutants (Hall \& Gallant, 1972; Travers, 1976). Micro-aerophilic conditions could enhance the regulation of transcription such that only appropriate proteins are made resulting in the transition from small unhealthy non-flagellated cells to large healthy flagellated rods which support phage growth. The ability of standing stationary phase cells to carry out essential activities more efficiently is emphasized by the greater viability of the cells, increased resistance to u.v. irradiation and heat, higher ATP concentrations and increased leucine transport. The regulation of all these physiological responses could be controlled by the effect of aeration on transcription in stationary phase cells. It is more likely that aeration will affect a single essential core process rather than a component of each individual activity.

As the different levels of protein synthesis in shaken and standing stationary phase cells could have been due to variations in the ability of the cells to transport $\left[{ }^{14} \mathrm{C}\right]$ leucine, it was important to determine the effect of aeration on leucine uptake. The reduced incorporation of $\left[{ }^{1} \mathrm{C}\right]$ leucine into protein in standing stationary phase cells is not due to the inability of the cells to transport leucine. Standing cells were actually shown to have a far greater capacity for leucine uptake than shaken cells.

The Vibrio strain is highly proteolytic and produces proteases in aerated stationary phase cultures which could be utilized for the degradation of pre-formed proteins and the recycling of amino acids. The inability to grow phage in aerated stationary cells could be due to amino acid starvation as a result of the inhibition of the transport of the amino acids released by the proteases. Leucine uptake was studied as an example of an amino acid transport system. Aeration of stationary phase cells markedly reduced leucine transport but it was not completely inhibited. As high concentrations of $\left[{ }^{1} \mathrm{C}\right]$ leucine are incorporated into proteins in shaken stationary phase cells, it is suggested that the levels of amino acids are not limiting and that the low level of leucine uptake is sufficient.

Since these are the first studies on leucine transport in a Vibrio strain, it is interesting to compare them with similar studies in E. coli. The kinetics of inhibition of leucine transport by isoleucine were similar to those of $E$. coli. The major component of the transport system represented $90 \%$ of the total leucine uptake and is a shared system for leucine and isoleucine uptake, analogous to the E. coli LIV system (Wood, 1975). The residual $10 \%$ of transport activity represented the minor leucine-specific system which probably has a high affinity for leucine. Growth of the Vibrio cells in a medium containing leucine increased the major transport system whereas in $E$. coli it is repressed by growth in leucine (Wood, 1975). The $K_{\mathrm{m}}$ for the shared transport system is similar in both Vibrio and E. coli.

Nierlich (1978) suggested that the controls of slowly growing $E$. coli cells have evolved to provide rapid adaptability. The ability of stationary phase Vibrio cells to react immediately to aeration conditions is demonstrated by the rapid decrease in protein synthesis on removal from shaking. Although an improvement in the environmental conditions is suggested by the increase in cell size, production of flagella and more resistant cells, there is a decrease in protein synthesis which differs from slowly growing $E$. coli cells where an immediate 
increase in the rate of protein synthesis occurs after enrichment (Koch \& Deppe, 1971). The substantial physiological and morphological changes represent a stationary phase differentiation or regulation system which is controlled by aeration. Few studies have been carried out on the regulation of non-sporulating stationary phase cells and the control mechanisms in stationary phase cells may be different from those operating in growing cells (Koch \& Deppe, 1971; Nierlich, 1978). The stationary phase phage growth system provides a unique experimental system for studying differentiation and possible changes in template specificity in a non-sporulating Gram-negative bacterium.

D.R.W. acknowledges research grants from the South African Council for Scientific and Industrial Research.

\section{REFERENCES}

Eichenlaub, R. \& Winkler, U. (1974). Purification and mode of action of two bacteriocins produced by Serratia marcescens HY. Journal of General Microbiology 83, 83-94.

ForchHammer, J. \& Lindahl, L. (1971). Growth rate of polypeptide chains as a function of the cell growth rate in a mutant of Escherichia coli 15 . Journal of Molecular Biology 55, 563-568.

Foulds, J. (1971). Mode of action of a bacteriocin from Serratia marcescens. Journal of Bacteriology 107, 833-839.

Hall, B. \& Gallant, J. (1972). Defective translation in $\mathrm{RC}^{-}$cells. Nature New Biology 237, 131135.

Koch, A. L. \& Deppe, C. S. (1971). In vivo assay of protein synthesizing capacity of Escherichia coli from slowly growing chemostat cultures. Journal of Molecular Biology 55, 549-562.

Lecroisey, A., Keil-Dlouha, V., Woods, D. R., Perrin, D. \& KeIL, B. (1975). Purification, stability and inhibition of the collagenase from Achromobacter iophagus. FEBS Lett:3rs 59, 167-172.

MandelstaM, J. (1957). Turnover of protein in starved bacteria and its relationship to the induced synthesis of enzymes. Nature, London 197, 11791181.

Mandelstam, J. (1960). The intracellular turnover of protein and nucleic acids and its role in biochemical differentiation. Bacteriological Reviews 24, 289-308.

NiERLICH, D. P. (1978). Regulation of bacterial growth, RNA and protein synthesis. Annual Review of Microbiology 32, 393-432.

Norris, T. E. \& KocH, A. L. (1972). Effect of growth rate on the relative rates of synthesis of messenger, ribosomal and transfer RNA in Escherichia coli. Journal of Molecular Biology 64, 633-650.
Pine, M. J. (1972). Turnover of intracellular proteins. Annual Review of Microbiology 26, 103-126.

Rahmanian, M., Claus, D. R. \& Oxender, D. L. (1973). Multiplicity of leucine transport systems in Escherichia coli K-12. Journal of Bacteriology 116, 1258-1266.

Roвb, S. M., Woods, D. R., Robb, F. T. \& StruthERS, J. K. (1977). Rifampicin-resistant mutant supporting bacteriophage growth on stationary phase Achromobacter cells. Journal of General Virology 35, 117-123.

Roвb, S. M., Woods, D. R. \& RobB, F. T. (1978). Phage growth characteristics on stationary phase Achromobacter cells. Journal of General Virology 41, 265-272.

Thomson, J. A. \& Woods, D. R. (1973). Properties of sphaeroplasts of a halotolerant Achromobacter strain and their infection with bacteriophage deoxyribonucleic acid. Journal of General Microbiology 74, 71-76.

Thomson, J. A. \& Woods, D. R. (1974). Bacteriophages and cryptic lysogeny in Achromobacter. Journal of Genercil Virology 22, 153-157.

Thomson, J. A., Woods, D. R. \& Welton, R. L. (1972). Collagenolytic activity of aerobic halophiles from hides. Journal of General Microbiology 70, 315-319.

Travers, A. A. (1976). RNA polymerase specificity and the control of growth. Nature, London 263, 641-646.

Wood, J. M. (1975). Leucine transport in Escherichia coli. Journal of Biological Chemistry 250, 4477-4489.

Woods, D. R. (1976). Bacteriophage growth on stationary phase Achromobacter cells. Journal of General Virology 32, 45-50.

Woods, D. R. \& Thomson, J. A. (1975). Unstable generalized transduction in Achromobacter. Journal of General Microbiology 88, 86-92. 